Living in the Interregnum: Existential Dilemma, Identity Crisis and Alienation in July's People

\author{
Submitted by \\ : Rania Reda Nasr \\ Under Supervision of: Dr. Gehan Al Margoushy \\ Department of English Language and Literature
}




\section{Living in the Interregnum: Existential Dilemma, Identity Crisis and}

\section{Alienation in July's People}

A review of the socio-political formation of South Africa demonstrates a clear racialized pattern of colonialism - of political oppression, economic exploitation and cultural subjugation. South Africa unfolds upon a history that is deeply rooted in colonial rule and white supremacy under Apartheid. It represents a system of 'internal' colonization separating settlers from natives; not only geographically but socially and economically, as well.

The Apartheid reinforced a racial hierarchy in a physical distance between racialized bodies. The term 'non-white' defined black people in relation to the master/slave relation that aimed to maintain the "purity" of white bodies. Michael Chapman points out how fear of "racial mixture and white determination to preserve racial purity were at this stage ... of key psychological importance to the appeal of apartheid: an appeal that found support among most whites" (221). Thus, various repressive acts were enforced to ensure this. In his critical study "The Continuing Salience of Race", Jermey Seekings states that the systematic racial classification of Apartheid was required to entail three main objectives. The first was ideological: to maintain racial purity by preventing mixing of white blood (non inter-racial marriage) and the residential segregation by race forcing the removal from 'white' areas. The second objective was: to ensure and protect the privileged economic position of white minority by reserving land for white ownership only. The third objective was: to maintain political dominance of white minority (giving no vote rights for blacks). Thus, the oppressive system of social division 
maintained and regulated by the Apartheid state was for the interest of white profit and white power.

Fanon and Mannoni both provide a psychology of colonialism representing the opposing parties of the conflict revealing, thus, the psychological as well as the political liberation and decolonization. Concurring with Fanon's superiority/inferiority complexes, Mannoni proposes two complexes illustrating the origin of colonialism: the superiority complex of Europeans and the dependency complex attributed to the colonized. The "superiority complex" constitutes "the main driving force of the Western man, and provides him with the energy which sets him apart from all other peoples in the world"(128). According to Mannoni, the black suffers from "dependency complex" and is in need of an authority to rule and protect him.

From his perspective, Hegel in The Phenomenology of Spirit proposes a master/slave paradigm to analyze the relationship between black and white and the origins of oppression. Hegel argues that man becomes conscious of himself only through recognition by the other. Thus, he defines the master/slave relationship in terms of recognition and not negation which leads to conflict if denied. The one who attains recognition becomes the master while the other who recognizes only without being recognized becomes a slave. It is then that the master oppresses and dehumanizes the slave. Hegel states:

Self-consciousness is faced by another self-consciousness; it has come out of itself. This has a two-fold significance: first, it has lost itself, for it finds itself as an other being; secondly, in doing so it has superceded the other, for it does 
not see the other as an essential being, but in the other sees its own self. (111)

However, Hegel argues that eventually the master would be a victim of his own privilege and advantage. Alienated from human labor and having not accomplished something concrete in life, the master loses himself while the slave reflects his humanity through his labor and achievements in life. By transforming nature, the slave could eventually transform himself and becomes the real victor in the relationship (111). In this context, Fanon states that one's existence is dependent upon the 'other being' and his recognition of him: "It is on that other being, on recognition by that other being, that his own human worth and reality depend. It is that other being in whom the meaning of his life is condensed" (Black Skin 216-217). Drawing deeply on Hegel's theory, Fanon states that the colonizer/colonized relationship is, thus, a derivation of the master/slave relationship where the one practices absolute power while the other is totally powerless. The two 'species' in Fanon's Manichean world are rendered lost in perpetual conflict of cultures, traditions, languages and values (Wretched 39).

To preserve the "racial purity" of the colonizers, segregation was enforced by white domination in South Africa. However, Goldberg argues that white supremacy and prosperity is dependent upon the presence of the non-whites and not their absence from the social formation, "but their controlled presence, their service of and obedience to white order and oversight ... They depend not on the absence of "nonwhites" from white space but their structured exploitation within it" (Racist Culture 50). This concept, thus, agrees with Hegel's theory of 'recognition' that states that both colonizer and colonized depend on each 
other for the achievement of self-determination and identification of each's identity.

In his critical study, Pedagogy of the Oppressed, Paulo Freire states that the oppressed reverses roles in his struggle for liberation and becomes the oppressor. He states that the oppressed "adopt an attitude of 'adhesion' to the oppressor ... their perception of themselves as oppressed is impaired by their submersion in the reality of oppression" (30). Freire argues that it is the "fear of freedom" that afflicts both the oppressor and the oppressed. This theory is further manifested in a double strategy: oppressors fear "losing the 'freedom' to oppress" as well as the oppressed who fear "to embrace freedom" (31). The oppressed, thus, suffers from a duality established in his psyche: "Although they desire authentic existence, they fear it. They are at once and the same time themselves and the oppressor whose consciousness they have internalized" (32). Freire further argues that the oppressed could achieve their liberation "only as they discover themselves to be "hosts" of the oppressor, in which they exist "to be like the oppressor"(32).

Thus, the aim to abolish the dehumanizing system of colonialism liberates both the colonizer and the colonized, oppressor and oppressed. In other words, Freire argues that an authentic liberation does not merely depend on the reversal of roles, "in moving from one pole to the other". Nor does it depend upon replacing "former oppressors with new ones" (43). He states that the oppressed seeks revolution as a means of "domination" rather than liberation; hence, Freire states that it is "absolutely essential that the oppressed participate in the revolutionary process with an increasingly critical awareness of their role" (121), which is to liberate rather than to dominate. 
In postcolonial theories, the problem of identity returns as a persistent theme in the course of study. Postcolonialsim flourished as a field of enquiry reflecting new cultural identities that emerged from oppressive regimes and emphasizing fragmentation and loss. Fanon's three phases of the native's response is manifested either in the assimilated culture of the occupying power, or in being disturbed and confused, or through rebellion. This process of dehumanization causes an identity crisis in the colonized:

Because it is a systematic negation of the other person and a furious determination to deny the other person all attributes of humanity, colonialism forces the people it dominates to ask themselves the question constantly: 'in reality, who am I?' (Wretched 200)

Fanon suggests that colonialism, with its concepts of white racial superiority over non-whites, has created a sense of division and identity crisis of the colonized expressed in Du Bois's "double consciousness"(Souls 2), i.e. the sense of always looking at oneself through the eyes of others. Since the culture and language of the colonizers are considered superior to the native's culture and norms, a strong sense of inferiority is established in the colonized subject, which leads to the adoption of the language and culture of the colonizer. As a result, the colonized assimilates the colonizer's mentality and considers himself superior to his own people and contempts his own cultural values. This creates a split in the identity of the oppressed and ends with his alienation from the self and from the society. 
A colonial territory characterized by economic oppression, political violence, racism and degradation, inevitably leads to alienation. Alienation is one of the most important themes in Fanon's theory. Fanon states:

In the man of color there is a constant effort to run away from his own individuality, to annihilate his own presence. Whenever a man of color protest, there is alienation. Whenever a man of color rebukes, there is alienation. (Black Skin 60)

Fanon posits five forms of alienation: estrangement from the "self" and one's identity, estrangement from the "significant other" exemplified in one's group, estrangement from one's cultural language and history, estrangement as an outcome of violence in relation between white and black; and lastly, estrangement as a result of denial of social activities (Black Skin 38). In the black/white confrontation, the black is faced with the reality of his "existential inferiority" (Black Skin 15) thus resulting in a clash between values and self-perception.

Within this colonial regime that subjugates people of their status as human beings, Fanon argues that the black is faced with" a feeling of non-existence" (Black Skin 139). This existential dilemma reflects the complexity of the colonial relation between colonizers and colonized, in South Africa. Nevertheless, Fanon argues that the native is not the only one alienated. The alienation of the white oppressor is caused by the racial hegemony the colonial regime engenders. The "superiority complex" opposed to the "inferiority complex" of the black, thus, gives rise to alienation: "The white man is sealed in his whiteness. The black man in his blackness" (Black Skin 11). Thus, Fanon uses the term 
alienation to represent conditions of separation of the individual from his self, his culture, or his society. It also describes a denial or suppression of individuality - a condition of hopelessness. He states, "I am speaking here, on the one hand, of alienated blacks, and, on the other, of no less alienated whites" (29).

Throughout a history of oppression by virtue of belonging to a certain race, this paper examines the psychological complexes rendered by such conditions as revealed in Nadine Gordimer's July's People. This paper explores not only poles of opposition which produce ambivalence in the colonial relation but also the resulting psychic dilemma and identity crisis. Gordimer has dramatized the history of her country by reflecting the oppression of the racist regime in her works. Many critics have called Gordimer an "interpreter" or even "the conscience" of South Africa (Clingman, The Novels of Nadine Gordimer 1) because she has consistently explored in her novels the lives and experiences of the oppressed in the racial setting and her fiction has been received as embodying a powerful moral critique of Apartheid. In July's People, Gordimer gives us a deep insight into the historical experience between the two forces of a superior white system and a rising African nationalism.

By examining the development of the Manichean relations in the Apartheid setting, Gordimer repeats a common pattern where the protagonists are confronted with the racial hierarchy and attempts to reevaluate their attitudes of the self and the other. Gordimer traces this identity crisis through the gradual disintegration and total alienation of her protagonists. In Manichean Aesthetics, JanMohamed states that while Gordimer examines the troubled consciousness of her protagonists and her desire to "bridge" the gap between the self and the society, this leads 
her "to a prolonged meditation about the dissolution and rebirth of the self that is constantly seeking to unite with its other" (146).

The conflict between the colonizer and the colonized reveals a set of paradoxes and ambivalence in the colonial relationship. Moreover, the decolonization process accompanied by a reversal of roles unfolds upon a more paradoxical relationship. This paper highlights the paradox and ambivalence in the colonial encounter and which are, thereby, reflected in the Apartheid narrative with its bleak yet massive presence imposed on twentieth century South Africa. Nadine Gordimer's July's People (1981) has been chosen for this purpose: as a document of the severe subjugation of the blacks on the African subcontinent, in contact to the neighboring West's democratic freedom as represented by white South Africans. It will also show the effect of the colonial setting of the Apartheid oppressive and racist regime on the colonial subject. Once the colonizer is deprived of a power that consolidates his sense of identity, he is faced with an identity crisis that eventually leads to his alienation. The main objective of this paper is to explore through the 'morbid symptoms' of living within new forms of definition and which is manifested in the identity crisis and existential dilemma that inevitably leads to alienation, not only of the colonized but also of the colonizer as well.

In the epigraph to July's People, Gordimer quotes a line from Gramsci's text Prison Notebooks to reflect an imagined moment of revolution in South Africa: "The old is dying and the new cannot be born; in this interregnum there arises a great diversity of morbid symptoms". Gramsci implies the death of the old and the inability of the new to be born, thus, implying the uncertainty of the future. In this period, Gordimer emphasizes the 'morbid symptoms' of the anxieties and contradictions that characterize the situation to foreground her views on 
the racial co-existence and national unity in a new and emerging unstable society (Clingman 193). The space between the two transitional periods constitutes a complex situation that is characterized by confusion, contradictions, and reversal of roles. Gordimer states, "The interregnum is not only between two social orders but also between two identities, one known and discarded, the other unknown and undetermined" (Essential 269).

Gordimer's concept of an interregnum is a period that is characterized by ambiguities, uncertainties and contradictions. Gordimer's novel indicates that the process of political transition to black rule requires a redefinition of roles and a re-evaluation of values. The interregnum can be conceived as a phase of Bhabha's "in-betweeness" or Hegel's "disintegrated consciousness" in a period of political transition. Thus, post-apartheid South Africa constitutes a state of interregnum where the old oppressive regime is preventing the birth of the new. Gordimer's view of the interregnum as depicted in July's People provides a critical analysis of a political transition between the overthrow of the previous white racist regime and the emergence of black majority rule and the difficulties that arise in such a process. According to Erritouni, it is a "dystopian" critique of Apartheid South Africa with a "utopian" projection that anticipates a more post-apartheid attitude. The novel foresees the inevitable collapse of white South Africa and the emergence of new political and social realities that gives the country a new national identity $(68,69)$.

The novel opens on a "bourgeois white family", Maureen and Bam Smales and their children, who are forced to escape from the burning city for the rural African village of their servant, July. Having "nowhere to go" (18), the Smales flee the violence of the city with their servant who 
leads them through back roads to his Kraal "a habitation of mud houses occupied only by members of his extended family" (12). Their new life is contrasted to "a seven-roomed house and a swimming pool" (25) of their previous life, thus, reflecting the racist system. Finding themselves accommodated in a hut and stripped of all privileges, their identities gradually crumble as they lose power of their economic status. The Smales hopelessly cling to old forms of power manifested in symbols of the car, its keys, gun, radio and toilet paper (Thurston 95).

However, Gordimer highlights the psychological battle that shapes the relationship between Maureen and July that dominates throughout the novel. In his analysis, JanMohamed states that Gordimer's main purpose is to examine the Manichean relations in such an "apocalyptic" setting (139). He further states that Gordimer's fiction "recognizes the traumatic presence of racism and graphically depicts the oppression of blacks, but her major pre-occupation is always the personal and moral dilemma that her protagonists suffer due to their encounter with apartheid" (147). At the end of the novel, when Maureen hears a helicopter landing, she runs towards it not knowing nor caring if it carried "saviors or murderers" (158). She runs abandoning her husband and children, claiming no responsibility "like a solitary animal at the season when animals neither seek a mate nor take care of young, existing only for their lone survival" (160). The novel ends on this ambiguous note, with Maureen rushing off to the unknown.

Smith states that both Maureen and July are unable to go beyond their fixed roles, unable to perceive new roles of definitions because "centuries of white dominance lies behind them"(149). When July's wife, Martha, tells him: "You could have a shop here, sell soap and matches... And now you can drive. For yourself"(135), July refuses and holds on to 
the fixed established norms of dependency. July views his relation to the Smales as "rooted in his status as a servant" (Smith 150).

The novel, then, reverses the concept of inferiority and dependency of the master/slave relationship for it creates a situation where whites are forced and resist to re-perceive the blacks within a violent revolutionary setting imagined by the author. Gordimer gradually portrays the reversal of roles that the new situation engenders. Caught "in a dramatic reversal of roles", the Smales are forced to re-evaluate their relation to July (JanMohamed 142). Acknowledging the emerging power, July

had seen the white woman and the three children cowered on the floor of their vehicle, led the white face behind the wheels in his footsteps, his way the only one in a wilderness, was suddenly aware of something he had not known. - They can't do anything. Nothing to us anymore... here they haven't got anything-just like us. $(21,22)$

In the novel, material possessions assume symbolic dimensions as Gordimer draws the reader's attention to the new connotations associated with them in the transforming social ethos. Gordimer employs the bakkie (car) and the gun as devices through which the characters become aware of their new identities and power relations that emerge out of the reversal of roles. JanMohamed (141-143) and Thurston (100-103) analyze the conflicting relationship between Maureen and July, positing it into three major confrontations. The first confrontation involves the control of the car keys, the bakkie. Symbolizing economic power and technology that maintained whites' privilege over blacks for many years, the car becomes an important aspect of definition to establish the identity of the Smales. On the other hand, July's control over this technology symbolizes the 
reversal of roles for the blacks to take over. The scene reflects Maureen's challenge and resistance as well as July's struggle for self-realization and recognition. The confrontation indicates Maureen's disintegration in contrast with July's growing sense of power and authority. Thus, "in struggling over the car, both master and slave are fighting to control the means of their independence" (JanMohamed 142). Maureen's eventual decision to 'hand over' the car keys to July implies the main theme that foreshadows the novel of white power handling over their authority to black rule in South Africa.

The second battle between Maureen and July was when July objects to Maureen's working with the African women in the fields. $\mathrm{He}$ insists that she does not do her laundry and prevents Bam from collecting wood. Thurston maintains that July's status among his villagers as an urban black is derived from his employers' status as a white economist. July develops his sense of authority and power amongst his people through his two contrasting images of himself as July, the urban servant, and as 'Mwawate', the villager. Thurston further states that the broken hut manifests his break with his traditional past, and his protection to the car is "a symbol of July's connection with his urban past and his aspiration for the future (101). Before the revolution, his people perceive him as a source of money, thus, his importance is measured in economic terms. By being "host" to the Smales after the revolution, his source of income is threatened. Thus, any inferior work made by his employers would degrade his identity among his people. He, furthermore, wants to ensure that his employers are unable to establish any relation with other villagers in order to be completely dependent upon him.

When Bam's gun is stolen, Maureen and July have the third and final confrontation. Reflecting her "fear to lose power" in a scene that is 
most powerful in the novel, Maureen insists that July recovers the stolen gun and accuses him of stealing items from her house in the past. Rejecting his old subservience role, July refuses "servant's formula" (94) of their last confrontation. He tells Maureen "How I must get that gun? ... You know where it is? You know? Then if you know why you yourself, your husband, you don't fetch it? (150). July enforces his speech with a dismissive signal from his hand as resistance to the former servant code "His hands flung out away from himself" (151). Gordimer vividly portrays the deadly scene that shatters any perceived roles between them: "She was stampeded by a wild rush of need to destroy everything between them; she wanted to erase it beneath her heels as snails broke" (152).

The third conflict signifies the climax of the novel, Maureen finally understands the relationship of dependency and subordination of her servant for fifteen years; what it meant for him to "ask for everything. An aspirin. Can I use the telephone. Nothing in that house was his" (155). He was oppressed and subordinated to a status of "total dependency" (155). Furthermore, Maureen's employment of July contributes to the oppression of black workers within the Apartheid system and that entitles blacks to be employed in the city by "passes" and visit their families in rural areas once every two years. After losing all comforts of her white society, Maureen has come to realize the oppressive conditions in which the black South Africans have existed under Apartheid.

Accordingly, Gordimer emphasizes the relationship between material possessions and power in the novel. Being accustomed to a life defined by economic security and ownership, the Smales' sense of self is shattered as they are unable to adapt themselves in the new environment. Now dispossessed politically, culturally and economically they cling to 
their few remaining belongings in order to maintain their identities. In his critical study, "Apartheid Inequality and Post Apartheid Utopia", Ali Erritouni states that "This disjuncture between the Smales' political and economic views accounts for their inability to understand the nature of July's claim on their car" (74). Gordimer, thus, emphasizes that it is not sufficient to sympathize with the blacks, reject racism and object to the policies of Apartheid. Sharing properties equally is demanded for white South African liberal position. In her essay "Apprentices of Freedom", Gordimer stated her belief that "racial problems, both material and spiritual, can hope to be solved only in circumstances of equal economic opportunity" (2). In this context, July's People changes the social ethos and reverses the roles set by the Apartheid racial system to redefine the relationship between different races. The concept of dependency and inferiority is replaced as Maureen is forced to re-perceive her servant and acknowledged his human rights; in other words, to see him in a new role beyond his restricted role as a servant. In her article, 'Living in the Interregnum', Gordimer emphasizes the importance of whites to accept new roles and find 'new perceptions' (266) in their relationships with the blacks and which necessitates the transformation process of South Africa. Gordimer states:

The hierarchy of perception that white institutions and living habits implant throughout daily experience in every white, from childhood, can be changed only by whites themselves, from within. (265)

Gordimer's imaginative disintegration of the Apartheid system also takes place in the deterioration or uselessness of the superior language. The crisis of the role reversal exposes the lack of communication between the two races - one bound to political marked places enforced by the 
Apartheid policies of colour bar while the other enjoys privilege in all its forms. In her new environment, Maureen fails to find the words to express the real oppression of the Africans: "No fiction could compete with what she was finding. She did not know, could not have imagined or discovered through imagination" that "they had nothing" (29). Language in the novel is caught between the old and the new: "For him, too, there had always been something to say: the servant's formula, attuned to catch the echo of the master's concern" (94). According to July, the English language "back there": is a symbol of subservience - "an English learned in kitchens, factories and mines. It was based on orders and responses, not the exchange of ideas and feelings" (96). When Maureen "didn't understand him", she thinks, “the black man's English was too poor to speak his mind" (97). The kind of English language that July has acquired appears limited to socio-economic exploitative relationship: "They could not read him....back there, for fifteen years; but then they had put it down to the inevitable, distorting nature of dependency" (60). The Apartheid system only taught July to communicate only what was necessary to allow him to perform tasks for his "masters" where the "vocabulary was limited to orders given by whites and responses made by blacks"(45). July remains trapped in the language of Apartheid, the language of subservience for blacks, the language of the past that the novel attempts to subvert by exposing its limitations in the new environment. With the reversal of roles, "Now he chose what he wanted to know and not know. The present was his; he would arrange the past to suit it" (96).

In their last and strongest confrontation, Maureen's illusions are finally shattered as July bursts out angrily in his African language:

Maureen understands although knows no word. What he had had to be, how she covered up to herself for him, in order for 
him to be her idea of him. But for himself ... to be intelligent, honest, dignified for her was nothing; his measure as a man was taken elsewhere and by others. She was not his mother, his wife, his sister, his friend, his people. (152)

In this scene and within a "revolution of language" (Clingman 200), Gordimer presents her view of the African liberation as reflected in July's control over the language. Accordingly, Gordimer portrays every action and attempt at communication as blocked by cultural, racial and language barriers between black and white South Africans. The novel, thus, examines language and cultural difficulties maintained by Apartheid within the context framework of role reversal. In this context, Smith states, "The paradox which epitomizes the deadlock of the book's ending is that only when the black man refuses to talk the white woman's language is she able to understand 'everything'"(152).

The unsettled and disturbed relationship between Bam and Maureen reflects the disintegrating white power in South Africa. Displaced socially and politically, the Smales' sexual status degenerates. They no longer know each other as they did before. Maureen fails to recognize in Bam the previous traits of the suburban architect. For a moment she has "a single throb of impulse to go over to the man and sink against, embrace him, touch someone recollected, not the one who persisted in his name, occasionally supplying meat, catching fish for people" (93). Maureen felt as if the man she had married had been "left" behind in the master bedroom; what was here with her, "was some botched imagining of his presence in circumstances outside those the marriage was contracted for" (98). 
The relationship between Maureen and July emphasizes Gordimer's state of interregnum. Struggling violently her new situation of dependency on July, Maureen clings to old elements of power and privilege as an assertion to her superior identity. With the disappearance of these elements, Maureen is left struggling between two modes of selfrealization: the old that is dying and the new that she resists and challenges. She is "no longer in possession of any part of her life"(139). Thus, as the Smales are struggling to maintain power through their possessions, they manifest the "morbid symptoms" in which identity is created by ownership. The loss of all material possessions and loss of former traditional roles played a great part in Bam and Maureen's identity crisis because their identity was dependent on these privileges. They became July's possessions, "she and her family were fed by them... hidden by them. She looked at her servant: they were their creatures, like their cattle and their pigs"(96). Furthermore, with the disappearance of these privileges, their identity disintegrates as they suffer the "morbid symptoms" of the interregnum. In his article, 'Masters and Servants', Smith points out that the only element of identity which remained constant for Bam and Maureen in their new existence was the fact that "They are white. They are seen as white and they are treated as white. Relations with all their new neighbours are affected by their alien whiteness" (148).

Within the context of this new ambivalent relation of dependency JanMohamed argues that the novel reflects a "struggle of consciousness"(140). He states, "While the dissolution of the master/slave relationship produces a corresponding disintegration of the master herself, ironically the resultant insecurity makes Maureen cling even more tenaciously to the servant" (142). In the novel, Gordimer 
portrays this dependency: "Always a moody bastard ... she had indulged him, back there. She had been afraid - to lose him, the comforts he provided" (64). Only when the reader thinks she is referring to her husband Bam, it turns out to be July she is referring to.

From another perspective, we encounter a black servant from the very beginning of the novel who is very much assimilated in his masters' culture, adopting their language and values. July is "adrift" from his culture and family (Thurston 101). Exemplifying Mannoni's inferiority complex, July strives hard throughout the story to preserve his status amongst his masters and his people. Split between July, the servant, and Mwawate, the villager, it seems clear that July has chosen to be assimilated and absorbed within the white culture and considers himself superior to his own people. Although July has always refused to carry his passbook, the degrading symbol of racial subservience, in his new awareness to power, he cannot destroy it:

He thought of the pass-book itself as finished. Rid of it, he drovr the yellow bakkie with nothing in his pockets. But he had not actually destroyed it. He needs someone.... to tell him to burn it, let it swell in the river, Bam's signatures washing away. (137)

Even within the reversal of roles and the shift in power, July still attains his sense of power and control through his masters and is yet dependent upon their previous superior image to preserve his identity among his people. This is evident in his clash with Maureen when he refuses that she shares any work with the African women. Thus, July experiences an identity crisis and existential dilemma only through the abolition of white power, not conversely: "I'm the boy for your house, 
isn't it?" (71). Thus, July represents Bhabha's concept of one's identification in relation to others as well as Freire's theory of "fear to embrace freedom". Rendered lost and alienated, July lays "in-between" the African and the white cultures, not belonging completely to either.

Paradoxically, July's control over the car and the keys and his insistence to drive reflects his growing sense of power and manifests his desire to achieve recognition and, in Fanon's terms, an 'independent selfconsciousness' (219). Within new roles and definitions, July ends the split between being identified in relation to his masters from one point and his attempts to replace them and take over forms of power. Thus, July longs for recognition and acceptance in new terms other than subservience and slavery. This is unfolded throughout his confrontations with Maureen and by which her resistance denies him his right to this recognition. July's need for recognition and redefinition is reflected in the split identity that he develops as an urban worker and as 'Mwawate', the villager. July is lost and alienated as he plays the role of a servant, host and villager at the same time. The contrasting images of the character of July runs parallel with Maureen's as she struggles between her identity as a madam of which she fights to preserve, and her new identity as a guest adjusting within new forms of definition. Drawing on Hegel's concept of mutual recognition and Fanon's theory of self-consciousness, we can see that the dominant impression of loss and disillusionment prevails at the end of July's People highlights the identity crisis of Gordimer's main characters who fail to attain recognition of one's self and the other.

Drawing upon Hegel's The Phenomenology of Spirit, this paper explores the concept of interregnum in Gordimer's description of Maureen's mental state as a state of Hegel's 'disintegrated consciousness'. By presenting the character of Maureen as a 
representation of resistance to change, Gordimer explores the failure of the central characters to achieve self-realization and as Hegel states, 'to recognize themselves as mutally recognizing one another' (Hegel 111). Hegel further states that 'self-consciousness exists in and for itself when, and by the fact that it exists for another; that is, it exists only in being acknowledged' (111). Maureen's denial of recognition of July's being and which is exemplified in her continuous conflicts with him, thus, constitutes an act of resistance to his achieving self-realization. We can deduce that the interregnum manifests the obstacles to July's attainment of self-consciousness as well as Maureen's failure to recognize and acknowledge his being and which signifies the failure of the whole process of decolonization.

According to Gordimer, the whites do not acknowledge the presence of the blacks, that is, they seek the blacks in the form of 'nonseeing' ("Interregnum" 265). Gordimer stresses on the complete negation of black identity whether denying their existence or distorting their image as being inferior and subordinate. Accordingly, the dismantling of Apartheid should require physical and psychological changes; that is, not only a reversal of the racist social structure, but also new definitions in accordance to each other. Failing to 'mutually recognize one another' (Hegel 112), Gordimer proposes her pessimistic view of the future of South Africa, which is manifested in the ambiguous interpretations of Maureen's flight. This further reflects Gordimer's pessimistic vision of the demise of the whole system of the Apartheid in South Africa. Maureen's flight at the end of the novel reinforces her resistance to the redefinition and social transformation of both races that the revolution demands. Reflecting Hegel's concept of lord/bondsman relationship, both parties remain: 
unequal and opposed, and their reflection into a unity has not been achieved, they exist as two opposed shapes of consciousness; one is the independent consciousness whose essential nature is to be for itself, the other is the dependent consciousness whose essential nature is simply to live or to be for another. The former, the lord, the other is bondsman. (115)

The sense of loss and disillusionment that prevails at the end of the novel reflects the rejection and failure of the whites to "redefine" themselves within new forms that is unbiased and equal to the blacks. Thus, Maureen is rendered lost, alienated and "cast totally adrift" whereas July's alienation is not ultimate since there is hope of regenerating his African identity because of his deeply rooted consciousness (Thurston 102).

Offering a solution, Gordimer states in "Living in the Interregnum" that white South Africans have to give up or share their possessions of economic wealth since their wealth was primarily constituted from the injustices of the Apartheid regime and the oppression of the blacks. She notes "In the eyes of the black majority which will rule, whites of former South Africa will have to redefine themselves in a new collective life within new structures ... A more equitable distribution of wealth may be enforced by laws" (265). However, Gordimer has revealed the difficulty that will be faced by future generations:

Whites have developed a totally unreal idea of how they out to live, of their right to go on living in that country. Consequently, they must undergo a long process of shedding illusions in order fully to understand the basis for staying in South Africa. Unfortunately, there aren't enough people who 
have the will to attempt this. It's very hard to peel yourself like an onion, without producing a lot of tears in the process. Yet it is absolutely necessary for anybody who wants to stay. (“Conversation” 196)

Thus, Gordimer maintains that the whites in South Africa must exert hard efforts in order to gain a place as an African and a national identity. In this context, Fanon asserts that "it is through the effort to recapture the self and to scrutinize the self, it is through the lasting tension of their freedom that men will be able to create the ideal conditions of existence for a human world"(Black Skin 231). This is definitely applied to the colonizer and the colonized as well.

To conclude, Maureen's flight illustrates the resistance to the reversed roles that the political transition engenders. Reflecting the white's alienation and existential dilemma, Gordimer states:

The black knows he will be at home, at last, in the future. The white who has declared himself or herself for that future... does not know whether he will find his home at last. ("Living" 270)

Thus, Erritouni maintains that the main theme that Gordimer posits in not who will rule but the "utopian vision of a democratic South Africa, led by the black majority, and the role South African whites would play in the new dispensation"(68).

Drawing upon the proposed theories of rejection and dependency, we can see how Maureen in July's People represents the colonizer, yet still needs to be "recognized" by her servant July in order to fulfill her superior sense of identity. On the other hand, while July rejects the oppressive degrading system of Apartheid and the master/slave 
relationship, he is yet dependent upon the Smales to preserve his image amongst his people.

Failing to recognize or be recognized, fearing to lose power or to "embrace" freedom, the colonial subject is rendered lost and alienated. The superiority/inferiority complexes persist in the collective psyche of both opposing groups hindering any of them to achieve either solidity or liberation. We have seen how July benefited from the revolution and used it as a means of power and domination, not liberation. Thus, Fanon's revolutionary violence or Freire's reversal of roles is insufficient to purge neither the whites of their superiority complex nor the blacks of their inferiority complex; they remain in an endless state of 'interregnum'. Accordingly, to attain self-consciousness and recognition, new roles of definition should be established based upon equality and non-privileges, where both poles of opposition begin to 'recognize' one another. 


\section{Works Cited}

Bhabha, Homi. The Location of Culture. London: Routledge, 1994.Print.

Chapman, Michael. Southern African Literatures. New York: Longman, 1996.Print.

Clingman, Stephen., ed. The Essential Gesture: Writing, Politics and Places. New York: Alfred A. Knopf, 1988.Print.

---. The Novels of Nadine Gordimer: History from the Inside. London: Allen and Unwin, 1986.Print.

Du Bois, W.E.Burghardt. The Souls of Black Folk. New York: Dover, 1994.Print.

Erritouni, Ali. "Apartheid Inequality and Poatapartheid Utopia in Nadine Gordimer's July's People". Research in African Literatures 37.4 Winter (2006):68-84.Print.

Fanon, Frantz. Black Skin, White Masks. 1952. Trans. Charles Lam Markman. New York: Grove Press, 1967.Print.

---. The Wretched of the Earth.1963. Trans. Richard Philcox. New York: Grove Press, 2004.Print.

Freire, Paulo. Pedagogy of the Oppressed. 1968. Trans. Myra Bergman Ramos. New York, 1970.Print.

Goldberg, D.T. Racist Culture: Philosophy \& The Politics of Meaning. Oxford: Blackwell, 1993.Print.

Gordimer, Nadine. July's People. New York: The Viking Press, 1981. Print.

---. "Living in the Interregnum". 1982. Ed. Stephen Clingman. The Essential Gesture: Writing, Politics and places. New York: Alfred A. Knopf, 1988.Print.

---. Living in Hope and History. New York: Farrar Press, 1999.Print.

Hegel, G.W.F. The Phenomenology of Spirit. Trans. A.V. Miller. Oxford University Press, 1977.Print. 
JanMohamed, Abdul. Manichean Aesthetics: The Politics of Literature in Colonial Africa. Amherst: University of Massachusetts Press, 1983.Print.

Mannoni, O. Prospero \& Caliban: The Psychology of Colonization.1968. Michigan UP, 1990.Print.

Seekings, Jeremy. "The Continuing Salience of Race: Discrimination and Diversity in South Africa. Journal of Contemporary African Studies 26.10 Jan (2008): 1-25.Print.

Smith, Rowland. "Masters and Servants: Nadine Gordimer's July's People and the Themes of her Fiction". Ed. Rowland Smith. Critical Essays on Nadine Gordimer. Boston: G.K. Hall and Co., 1990.Print.

Thurston, Barbara Temple. Nadine Gordimer Revisited. New York: Twayne Publishers, 1999.Print. 